\title{
"Y EL RESTO SE HACE CON GRITOS" \\ Notas sobre literatura y teatro
}

Marcela Arpes ${ }^{1}$

Universidad Nacional de la Patagonia Austral

\section{1.}

Quisiera comenzar con un, más o menos extenso, listado de obras de teatro que aún permanecen en cartel o, en todo caso, algunas de ellas lo estuvieron hasta marzo, en salas oficiales y alternativas del circuito teatral porteño pero, también, del interior del país: Tres para el té sobre textos de Lewis Carroll; Galileo, sobre la mesa

\footnotetext{
${ }^{1}$ Marcela Arpes es Profesora Adjunta Ordinaria en el área de Literatura Argentina desarrollando su trabajo de docencia en el Profesorado y la Licenciatura en Letras y de investigación en la dirección de Proyectos de Investigación relacionados con la Literatura Argentina contemporánea. Su estudio de Doctorado se orienta a pensar teóricamente la dramaturgia y el teatro argentino contemporáneo. Algunas de sus últimas publicaciones son: Encuentro de la Literatura Argentina con el Discurso Critico, Universidad Nacional de la Patagonia Austral, ISBN 987-962-88-7-X.(Comp. 2006), "El teatro de Rodolfo Walsh: una operación política aún vigente" en Revista Espacios. Nueva Serie. Estudios Literarios y del Lenguaje. Año II, Número 2, diciembre de 2006. ISSN 1669-8517, "Teatro para nosotros, teatro para los otros" en Revista El Hilo de la Fábula, Centro de Literaturas Comparadas, Universidad Nacional del Litoral. ISSN 1667-7900 (2007), "Escrituras de roce. Cuando la dramaturgia dice el ensayo" en Dramateatro, $\mathrm{N}^{\circ} 22$, Septiembre-Diciembre 2007. Venezuela., Literatura infantil argentina. Infancia, política y mercado en la constitución de un género masivo, Buenos Aires, Stella y La Crujía, Colección Itinerarios, ISBN 978-987-601-051-1 (libro en coaturía con Nora Ricaud, "Medea en tierras de España. Una versión posmoderna de la tragedia clásica por el dramaturgo español Fermín Cabal" en Aurora López - Andrés Pociña (eds.), En recuerdo de Beatriz Rabaza. Comedias, tragedias y leyendas de Grecia y de Roma en el teatro del Siglo XX. Universidad de Granada, España. (Cap. de libro en coautoría, en prensa) "Corpo perdido, corpo achado" en Boletim de Pesquisa NELIC. Edicao especial Lindes. Núcleo de Estudos Literarios y Culturais. SIN 1518-7284, Florianópolis, Univ. Santa Catarina, Brasil. (2008: 36-50), "Teatro para nosotros, teatro para los otros" en Revista El Hilo de la Fábula, Centro de Literaturas Comparadas, Universidad Nacional del Litoral. ISSN 1667-7900 (2008: p. 113-121) "Teatro, exilio y crítica periférica" en:

http://163.10.30.203:8080/congresos/congresoespanyola/programa/ponencias/ArpesMarcela.pdf, Universidad de la Plata (2009).
} 
sobre el texto de Bertolt Brecht; Federico tuvo un sueño, inspirada en el cuento de Antonio Tabucchi y en textos poéticos de Federico García Lorca; Los siete locos, de Roberto Arlt; Crave de Sarah Kane; Cielo rojo, el sueño Bolchevique del poeta Vladimir Maiacovsky; La Manchada, sobre Cuentos de la selva de Horacio Quiroga; Doña Flor y sus dos maridos de Jorge Amado; Grande y Pequeño del escritor alemán contemporáneo Botho Strauss; El diario de Anna Frank; Esa que no eres sobre textos de Alejandra Pizarnik, obra que recibió este verano el premio Estrella de Mar en la categoría mejor espectáculo del teatro off; La revolución silenciada sobre la obra Tres jueces para un largo silencio de Andrés Lizarraga, aquel escritor y dramaturgo argentino, el primero en recibir el premio Casas de las Américas; El mundo ha vivido equivocado de Roberto Fontanarrosa; Una vida más cuerda mañana, sobre textos de Griselda Gambaro, Sarah Kane y Vicente Zito Lema; La Divina Comedia de Dante Alighieri: Mi madre Mi Tierra donde conviven textos literarios de autores como Gloria Fuertes y Federico García Lorca; Sabor a Freud de José Pablo Feinman; El Corazón Delator de Edgar Allan Poe; El Relato de Lady Sotheby. de Marlene Spindler, espectáculo basado en textos de Fiodor Dostoyevsky y Stefan Zweig; Juicio al tango, sobre textos de Leopoldo Marechal; El día que Nietzsche lloró, título de la primera novela del profesor de psiquiatría de la Universidad de Stanford, Irvin Yalom; El último encuentro de Sándor Márai, versión escénica de la exitosa novela "El último encuentro" de Sándor Márai aquel escritor best-seller, antifascista, húngaro que fuera consagrado en el mundo entero luego de su trágico suicidio; El diario privado de Adán y Eva de Mark Twain; La Última Cena, sobre la novela de Dan Rosen; Fausto de Goethe; Una sociedad secreta, inspirada en el mundo poético de Roberto Arlt y Armando Discépolo. Además de los clásicos dramatúrgicos como Miller, Shakespeare, Chejov, Moliere, O'Neill, Pavlovsky, Gambaro, Beckett, Pinter, Sófocles y la enumeración sigue.

El caótico listado no tiene otra intención que proponer una nueva entrada para pensar el vínculo, inevitable si atendemos a estos títulos, entre teatro y literatura. Acumulación de títulos que pueden ser la prueba para cierto ejercicio crítico sobre la literatura metida en la escena. O la necesidad de la literatura para la escena y el rol de la palabra en el teatro. Quiero decir, más allá de las propuestas teóricas con las que se han innovado en los estudios teatrales desde los años '60 hasta acá -y que van desde la semiótica teatral pasando por la antropología teatral, 
la transdisciplinariedad artística y la multiculturalidad propuesta a partir de los años '90- y, más allá también, del tratamiento con que, en esos diversos momentos del desarrollo teórico, se ha abordado la relación representación/texto dramático, lo cierto es que la literatura sigue gravitando de manera significativa al momento en que un director o un grupo programa una puesta en escena. Como acertó en enunciar Beckett, el representante si se quiere de los intentos de disolución extrema de lo verbal o de la búsqueda de la palabra lacónica e incomunicante: "La única, la mínima, la indispensable palabra”. Expresión similar, en una versión nacional, la del dramaturgo Alejandro Tantanian para quien:

...sin embargo, oculta bajo la superficie aparentemente quieta de la acción, se halla la inequívoca tempestad de la palabra: arma primera y definitiva del teatro $^{2}$

Detenerse en los títulos en cartel nos enfrenta al dilema del valor de la palabra literaria, aun cuando se hayan postulado los juicios más extremos sobre su prescindibilidad. No quiero decir con esto que el teatro no tenga su especificidad estética, epistemológica y hasta filosófica. Sino que el intento vale para localizar al texto en el medio teatral, luego de todas las prácticas que han intentado destituirlo o disolverlo desde hace más o menos 20 años hasta acá. Pretender que el texto existe, desde el lugar de la literatura significa que, no obstante sea factible, como camino crítico y teórico, seguir apropiándose de los textos dramáticos como objetos poéticos, pensando a la escritura en el sentido de "literatura dramática" y, desde el lugar del teatro, el reconocimiento de que un "buen texto", con un lenguaje que supere la coloquialidad y extrañe la realidad, es tan importante como una iluminación significante, una escenografía no ornamental o las destrezas corporales de los actores. "El teatro es un arte de la palabra. La palabra pertenece al teatro y el teatro a la palabra" afirma Ignacio Apolo (2003:20), uno de los enfáticos y eufóricos integrantes del, en su momento, grupo Caraja-ji, grupo que a fines de la década del '80 en la Argentina se constituye en el referente, no sólo de una escritura dramática lindante con los procedimientos de la escritura literaria, sino también del regreso de

\footnotetext{
${ }^{2}$ Texto incluido en el programa de mano de La Tercera Parte del Mar en ocasión de su estreno. La obra se estrena en abril de 1999 en la sala Babilonia de la ciudad de Buenos Aires, bajo la dirección de Roberto Villanueva.
} 
la tradición del "autor dramático" luego de los numerosos proyectos anti-logos de la práctica teatral durante la postdictadura.

Si nuevamente convocamos los títulos del inicio, ellos remiten directamente a obras de la literatura o a apropiaciones de ella. Desestimo aquí, no por importante sino porque me desviaría del tema, lo que significa el proceso de adaptación dramatúrgica, como procedimiento de transcodificación e intertextualidad en el camino que se emprende al tomar como base verbal de la representación un texto literario de cualquier género, como lo ejemplifican los casos expuestos. Es decir, no leo ese listado desde las implicancias teóricas que se puedan desprender a propósito de la tarea de adaptación pero sí sólo una acotación: desecho desde ya las posturas, por lo menos anacrónicas, que ubican a la adaptación como vulgarización o degradación del texto literario original o como traición al sentido primigenio del mismo. ${ }^{3}$

Desde los años '60, la palabra en el teatro ha sido puesta a prueba, tensionada, distorsionada, corroída, en parte, a partir de las experimentaciones propias en el terreno espectacular -pensemos en el absurdo, el happening y los inicios de las prácticas preformativas- pero también a partir de diversos procedimientos poéticos antes ensayados en el terreno literario que se trasvasaron a la escritura de los dramaturgos. Como sabemos, en 1963 comienza a funcionar en Buenos Aires el Instituto Di Tella que se convertirá rápidamente en el reducto de la innovación plástica y teatral en la Argentina. Un espacio propicio para la improvisación, la creación colectiva, el balbuceo escénico. En efecto, de allí surge el

\footnotetext{
${ }^{3}$ Me parece oportuno, a propósito de este tema, citar un fragmento de un texto de Gilles Deleuze que introduce la noción de autor menor. "El hombre de teatro ya no es autor, actor o escenificador. Es un operador. Por operación es necesario entender el movimiento de la sustracción, de la amputación pero ya recubierto por el otro movimiento, que hace nacer y proliferar algo inesperado, como en una prótesis (...) Pero por ejemplo, él amputa a Romeo, neutraliza a Romeo en la pieza original. Entonces toda la pieza, dado que le falta un pedazo escogido no arbitrariamente, va quizás a oscilar, a girar sobre sí misma, a colocarse sobre otro lado. Si amputáis a Romeo, vais a asistir a un sorprendente desarrollo, el desarrollo de Mercuzio, que sólo era una virtualidad en la pieza de Shakesperare" El desarrollo del filósofo es a propósito de la versión de Romeo y Julieta de Carmelo Bene ubicando su práctica como resultado de la actividad de "autor menor" ya que "(...) No se trata ni de lo histórico ni de lo eterno sino de lo intempestivo. $Y$ es precisamente esto un autor menor, sin porvenir ni pasado, él sólo tiene un devenir, un medio, por el cual comunica con otros tiempos, con otros espacios" (1-2).
} 
absurdo y de allí todos los intentos de transdisciplinariedad artística (Pellettieri, 1994; Dubatti, 1998).

Sin embargo, desde fines de la década del '90, y no sólo en la Argentina, el teatro se enfrenta al nuevo desafío de redefinir sus lazos con la literatura o en la literatura, olvidando la idea de considerar al texto dramático como su hijo bastardo. Sin indagar en la configuración en sí de esta dramaturgia, es decir desde una ubicación de exterioridad a la propia ficción dramática, se pueden precisar algunos acontecimientos: la recurrencia a la literatura como base de la instancia espectacular, la designación y autodesignación de "escritores" a los dramaturgos desplazando así las denominaciones al uso de "hombre de teatro", los concursos de dramaturgia que se organizan desde iniciativas oficiales y privadas, y las ediciones, cada vez más numerosas, de dicha escritura puestas a circular con la lógica del mercado de la literatura. Reconocer estos hechos sucediendo de manera simultánea, nos habilita a conjeturar la hipótesis de un debilitamiento de las fronteras infranqueables que las vanguardias modernizadoras del teatro de principios del siglo $X X$, desde el atrevido "Merde" de Jarry hasta la lapidaria sentencia artaudiana de "nuestro teatro vive bajo la dictadura de la palabra", se esgrimieron como una apuesta al destierro verbal para darle a la escena lo que le es propio y devolver el teatro al teatro. Sospecho que nos encontramos ante la presencia de una revitalización de la palabra poética, una palabra literariamente concebida que exige, a los que nos dedicamos a los estudios teatrales, una posibilidad de reflexión que vaya más allá de las concepciones tradicionales sobre el tema y que abra nuevas alternativas teóricas y metodológicas para indagar la problemática. Porque, por un lado, el carácter de doble enunciación del texto dramático define ciertas peculiaridades al momento de tomarlo como objeto pero, por otro, cierta condición temporal de la escritura dramática que le es ajena y no la condiciona indefectiblemente. El texto dramático padece de una imposibilidad que, paradójicamente, es la que genera sus potencialidades más poéticas: “...demasiado restringido para la imaginación narrativa, demasiado prescriptivo para la entonación poética; su autonomía es, por decirlo, 'impura' (...) demasiado lingüística para la música, demasiado performático para la literatura. Demasiado mimético para la danza, demasiado narrativo para la plástica." (Apolo, 2003:21). 
Lo que el Apolo señala con esta no definición no es más que una caracterización potente del texto dramático donde su carencia y su indecibilidad se transforman en una fuerza en demasía. La clásica restricción limítrofe que desistía finalmente por el abandono del logos aristotélico a favor de la supremacía del terreno legítimo para el teatro, la escena, parece hoy desvanecerse en la configuración de un nuevo territorio teatral dable para la pregnancia de ambas zonas. Reconocer los intercambios desproveyendo a la noción de lenguaje o palabra de cierta subalternidad en el terreno teatral implicaría, por ejemplo, apropiarnos del concepto de confin, tal como lo piensa Raúl Antelo en relación con el uso del término teórico en Cacciari: "ou se preferirmos, a literatura e suas fronteiras, nos obriga, antes de pensarmos na fronteira ou no linde, a ponderar, de fato, uma série de esforços contemporâneos por transgredir os limites." (Antelo, 2008, inédito).

La literatura y el teatro ahora en una zona donde los límites no son rígidos sino todo lo contrario, confinados a una zona de contacto y de préstamos.

Quizás también, la noción de escena expandida (Célis Alvarez, 2005) podría dar cuenta de esta ampliación de los límites, al tratar a la palabra teatral como expresión de fundamentos retóricos-dramáticos pero también, como expresión poética.

De hecho, la escena expandida involucra varias cuestiones. Por un lado, la superación del fundamento de la mímesis como mecanismo de representación. Entonces, las relaciones de mímesis en el arte contemporáneo se desplazan hacia otras formas de representación que se vinculan con la presentación, la indicación, la mostración de las propiedades de la ficción y la exploración de sus virtualidades. Y es a partir de esta noción que la metateatralidad entra a jugar un papel fundamental como ingrediente de la cocina ficcional dramática.

Por otro lado, la expansión de los límites de la estructura dialógica hacia un lenguaje fronterizo con lo narrativo y, principalmente, con lo lírico. La disolución del diálogo, práctica escrituraria cada vez más cultivada por los dramaturgos, se presenta como el gesto de enunciación discursiva que mina las proposiciones de "verdad" supuestos en el intercambio dialógico: "el modelo dialógico (técnicamente dramatúrgico) que Platón tomó prestado del teatro impuso en la cultura occidental el sentido de verdad en las obras de teatro, es decir, lo que fue un recurso para-teatral 
de la filosofía, hoy, aún cubre varios aspectos de la creación escénica." (Céliz Alvarez, 2005:6).

$Y$, finalmente, la transdisciplinariedad o transversalidad de las artes en el teatro. No sólo la literatura sino además, la música, la plástica y los recursos audiovisuales.

La expansión de la escena hacia la apropiación de estos territorios artísticos y la fundición con ellos; además de todo un sistema teórico que se apropia de la metáfora teatral para abordar las múltiples aristas de la realidad como espectáculo escénico -pienso en el ya clásico texto de 1967 de Guy Debord- provocó una reacción que se tradujo en interrogar la práctica teatral y dramatúrgica para lograr redefinir nuevamente la naturaleza del teatro. Así, esta necesidad se expresó, en la dramaturgia argentina surgida en la década del '90, en la opción por la escritura de modelos prescriptivos al estilo de los manifiestos vanguardistas, en formas de definición que podríamos denominar manifiestos teatrales posmodernos. ${ }^{4}$

De esta manera, la noción de escena expandida, tanto como la de confin y podríamos agregar en el mismo sentido, la de liminalidad (Dieguez, 2007) y la de ampliación del concepto de teatralidad previsto por Florence Dupont a propósito de la cuestión convivial, ${ }^{5}$ trazan el diseño de un esquema teórico que facilite la comprensión del controvertido vínculo entre literatura y teatro.

\footnotetext{
${ }^{4}$ Me refiero específicamente a las declaraciones de poética y autopoética dramáticas a manera de prólogos en la edición del grupo Caraja-ji, los prólogos, comentarios, epílogos que acompañan las ediciones de la obra de Rafael Spregelburd, escritos por el mismo autor, pero también al manifiesto de Daniel Veronese: Automandamientos para el nuevo milenio y el de Alejandro Tantanian: Sobre la dramaturgia joven. En otros trabajos he abordado la cuestión de los manifiestos: "La reinvención del teatro en la dramaturgia argentina actual" en Revista Semiosis llimitada. № 1 "El Otro" -Año 2002ISSN 16663683 (115-125), "Género y Ethos en los Manifiestos de la Nueva Era" en Revista Espéculo. Revista de Estudios Literarios, $\mathrm{N}^{\circ}$ 31, noviembre 2005, Universidad Complutense de Madrid, "Escrituras de roce. Cuando la dramaturgia dice el ensayo" en Dramateatro, $\mathrm{N}^{\circ} 22$, septiembrediciembre, Venezuela, 2007, "Teatro para nosotros, teatro para los otros" en Revista El Hilo de la Fábula, 2008, Centro de Literaturas Comparadas, Universidad Nacional del Litoral. ISSN 1667-7900 (113-121), "El lugar de la palabra en el teatro actual. Algunas apropiaciones teóricas 'derridianas' para pensar el problema" (2008, inédito).

${ }^{5}$ Propuesta teórica en la que se basan las formulaciones de Jorge Dubatti: "Los tres momentos de constitución del teatro en teatro son: el acontecimiento convivial, que es condición de posibilidad y antecedente del acontecimiento de lenguaje o acontecimiento poético, frente a cuyo advenimiento se
} 


\section{2.}

Cuando desde los estudios teatrales se discrimina entre teatralidad social y teatralidad poética, ${ }^{6}$ la distinción se basa fundamentalmente en ese carácter de constructo ficcional, de creación de subjetividad, de exigencia metafórica con que se concibe la teatralidad poética. Y poético allí, está usado en el sentido clásico aristotélico de poiesis: "el teatro, en suma, como espacio de subjetividad y experiencia que surge del acontecimiento de multiplicación convivial-poéticoexpectatorial" (Dubatti, 2008:44).

El debate acerca de si la escritura dramática pertenece a la literatura o es de una especificidad tal que debe considerarse fuera de ella, no ha tenido fin y ha sido objeto de consideraciones teóricas permanentes: Veltrusky (1990), Ubersfeld (2002), Féral J. (2004), Alfonso de Toro (2004, 2007), Pavis (1999, 2002), Dubatti (2002, 2008). Así, en algunos momentos del desarrollo del sistema teatral las instancias de producción han optado por la devaluación de la palabra pensándola, o bien, como un código más dentro del resto de los códigos escénicos con función comunicativa -consideración que se inscribe en la estela teórica de la semiótica teatral- o bien, para priorizar los otros signos escénicos en detrimento de éste. Buena parte de la dramaturgia actual es heredera de la escritura escénica en el sentido de escribirse como resultado de un trabajo primero sobre el escenario a partir del aporte de los actores. En el panorama que se desenvuelve bajo la denominación de teatro argentino actual ${ }^{7}$ conviven tres tipos de dramaturgias: la de autor, la de dirección y la

produce el acontecimiento de constitución del espacio del espectador. El teatro acaba de constituirse como tal en el tercer acontecimiento y sólo gracias a él. Sin acontecimiento de espectación no hay teatralidad, pero tampoco la hay si el acontecimiento de espectación no se ve articulado por la naturaleza específica de los dos acontecimientos anteriores: el convivial y el poético".

6 "Por lo tanto me atrevo a dar un paso adelante, y digo: teatralidad social vs teatralidad poética. Hay dos grandes campos de teatralidad y me corresponde pensar el campo de la teatralidad poética en oposición, en diversificación, en separación de la teatralidad social" (7) Dubatti, J.: "El teatro morada habitable" en Revista Conjunto.

${ }^{7}$ La denominación está tomada de la periodización establecida por Jorge Dubatti (1999:9) quien entiende que el teatro argentino actual es la producción escénica y dramatúrgica que se desarrolla a partir de la posdictadura en diferentes líneas estéticas ideológicas. 
de actor que se inscriben en proyectos estéticos diversos. La improvisación y el ensayo sobre el escenario se convierten, en la dramaturgia de dirección y de actor, en el a priori escriturario y allí el dramaturgo cumple el rol de captador, catalizador y mediador de lo, primeramente, escrito con el cuerpo del actor. Allí el autor teatral asume la escritura de una partitura (Monti, 2002:63) desde una vocación escénica más que literaria. Pero también existe, como ya hemos descrito anteriormente y es aquí donde quiero detenerme, la dramaturgia de laboratorio, de escritorio, de la escritura en soledad que se genera en una escena de enunciación análoga con la de la literatura en general. O en otros términos, la literaturización de la escritura teatral.

Alejandro Tantanián aventura una especie de solución al problema de pertenencia e incumbencia de lo literario en lo teatral y a la inversa. En efecto, las obras por él escritas quedan desvinculadas del terreno de lo estrictamente teatral cuando no se han puesto en escena y entonces sólo son "literatura"; mientras que, si las obras se han estrenado, entran en el juego inevitable del presentismo y la dinámica de lo espectacular, del acontecimiento teatral (Dubatti, 2008:58) donde la palabra vale como un recurso más dentro de la codificación teatral. ${ }^{8}$

Más allá y más acá de todas las posibilidades de manifestación de la palabra en el teatro, de las taxonomías dramatúrgicas, del ámbito de inscripción de esa escritura, y también teniendo en cuenta muchas de las declaraciones de los dramaturgos referentes del teatro, la opción sería invertir el ángulo y pensar la escritura generada desde una vocación literaria y, entonces, desde esta perspectiva detenernos en lo que de permanente tiene en sí misma, más allá de su volatilidad en el acontecimiento teatral, mucho más complejo y regido por otras reglas. La dramaturgia de autor se presenta como la palabra poética que desafía la clásica lectura del texto teatral, no sólo para el lector en soledad sino también, para los lectores colectivos en la mesa de trabajo escénico y para los espectadores en la

\footnotetext{
8 "Sobre todo digo de las obras que se estrenaron -porque de las que no se estrenaron es como literatura-. Pero de las que se estrenaron hay tanta memoria en uno de un montón de otras cosas: de errores, de cosas maravillosas, de desastres, de... Entonces hay una relación con el texto teatral, estrenado al menos, que tiene otro orden, digamos". Entrevista realizada en junio del 2006 para el portal de Audiovideoteca del Centro Cultural Recoleta.
} 
representación. ${ }^{9}$ Si como declaran los manifiestos referidos, el lenguaje del teatro debe ser el de la palabra desarticulada, desmontada y rítmica de la palabra poética, si el autor debe sacar a la superficie aquella voz que se halla en el pliegue de la palabra normalizada de la comunicación cotidiana y del diálogo habitual, entonces, esto tiene mucho más que ver con la literatura que con el teatro.

$\mathrm{Y}$ aquí nos introducimos en el terreno no menos ripioso de la complicada paradoja a la que nos enfrentamos cuando deseamos pensar la dramaturgia. Si en un planteo más o menos sencillo y hasta ingenuo teóricamente, decimos que la poesía es la literatura del lenguaje porque su apuesta es el juego más o menos libre de los significados y significantes, y la narrativa es la literatura de la trama, el teatro es el género a medio camino entre los dos. ${ }^{10} \mathrm{O}$ es el género que con mayor permeabilidad a partir del siglo XX ha manejado las fronteras entre lírica y narrativa.

Explorar teórica y críticamente la dramaturgia como acto poético es, no sólo verificar el funcionamiento poético del discurso que afecta y conmueve tanto al lector como al espectador desde la escucha -sentido estricto del término motivo del pensamiento de Roman Jakobson (1963) y los formalistas rusos a propósito de los textos literarios- sino también, vincularla a la función poética propia del texto teatral que excede la retórica discursiva y se plasma, además, en una retórica de la representación (Ubersfeld, 1991, 1995), es decir, una poética teatral que ancla su sentido final en la alternativa de que los signos escénicos asuman las grandes figuras retóricas: objetos-metáforas, objetos-metonimias, personajes-metáforas.

\footnotetext{
${ }^{9}$ Ricardo Piglia entiende el valor del teatro como acontecimiento poético peculiar y también el valor de la palabra como aquello que trasciende justamente por su inscripción en lo literario: "A los escritores nos interesa mucho la experiencia del teatro leído, de leer obras de teatro. Me parece que es algo que no sé si forma parte de la historia del teatro. Pero la experiencia de la lectura de cierto tipo de dramaturgos forma parte de una experiencia contemporánea muy productiva. No puedo imaginar que el teatro como tal y la dramaturgia como tal desaparezcan de la escena. Por más que muchas posiciones experimentales tiendan a considerar que en realidad el teatro es una experiencia con los cuerpos. (Narradores y Dramaturgos, 2002:44).

${ }^{10}$ Una propuesta para comprender el diálogo complejo entre los tres géneros tradicionales se puede leer en Veltrusky J (1990). Desde una perspectiva que ancla en la diferenciación estructural y de función de los géneros tradicionales, el drama "logra una síntesis del lenguaje y la trama, en que los dos juntos son más que cada uno (lírica y narrativa) por separado." (114).
} 
Llegado hasta aquí, se impone entonces el concepto de teatro poético que de manera estricta ha sido formulado pensando casi exclusivamente en el teatro español, sobre todo a partir de la obra de Valle Inclán y de Federico García Lorca. El teatro poético español de estos dramaturgos se distingue por su composición musical en arias elegíacas y descriptivas. Pero además, en el teatro lorquiano, la irrupción de las escenas líricas desestabiliza lo dialógico generando un distanciamiento crítico por vía de la alucinación y fascinación poética. Si las escenas líricas de Brecht operan, como efecto de recepción, sobre la racionalidad de los lectores/espectadores, las de Lorca, lo hacen a través del embelesamiento irracional de índole surrealista.

El teatro poético parece reunir en una trama compleja varios elementos: el verso como ritmo a la manera de la composición en una partitura musical, el libre trabajo con la metáfora y las significaciones del lenguaje al límite y, la corrosión de la referencialidad. Todos estos principios constitutivos desatan las posibilidades simbólicas del lenguaje y de su tratamiento poético y orientan a "hacer de la propia palabra una experiencia" (Grüner, 1999:127) tal vez, también, en una futura puesta en escena.

Desde las vanguardias teatrales de fines del siglo $\mathrm{XIX}$ y principios del $\mathrm{XX}$ hasta este inicio del siglo XXI, el teatro ha querido desentenderse de su carácter referencial y va paulatinamente renunciando a la función explicativa, con lo que la obra dramática va prescindiendo de la necesidad de la fábula o la historia o el relato del "cuentito" como señala irónicamente Mauricio Kartún (2001). La escritura dramática actual se inscribe en estas contemporáneas configuraciones desviándose de la tradicional trama dialógica en un intento de desconstrucción de la palabra dramática a partir de la apropiación del paradigma literario, específicamente, de la poesía.

Y tomemos sólo un caso como ejemplo, el del texto de Alejandro Tantanian, Cine quirúrgico (2001) que se abre con la siguiente acotación que bien puede leerse como una evocación de aquellas escenas líricas de las didascalias lorquianas o bien, como un epígrafe:

Mi cuchillo es bello y afilado.

Y la belleza es terror domesticado.

Domestico, entonces. 


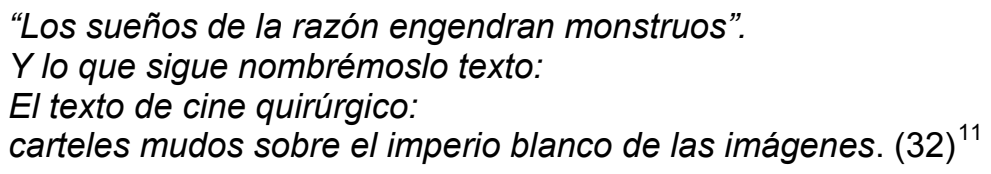

Esta obra breve no estrenada, tiene como protagonista a la figura del doctor Alejandro Posadas. El montaje de tono autobiográfico parte del supuesto hallazgo de material fílmico, fotografías, diagnósticos y archivos del científico. A la obra se la define, como "dramícula", Cine quirúrgico, cuya escritura surge de una lectura, interpretación y reescritura del material encontrado en diversos archivos. No es un drama en el sentido estricto al que alude el término en una concepción tradicional de dramaturgia. Es una deformación, una degeneración del drama y el sufijo se encarga de mostrar la zona de borde (Gerbaudo, 2007) en el que se habilitan intercambios y préstamos genéricos que desestabilizan la seguridad de la línea demarcatoria. Las remisiones textuales y la disolución de la identidad de los que escriben la dramícula son el gesto de, no sólo conmover el límite entre lo real histórico y lo ficcional, sino además, de exhibir las intromisiones y contaminaciones de dos zonas discursivas fuertemente codificadas que ahora ponen en duda la demarcación y la entidad de quien ha establecido tal límite. La obra que leemos es lo escrito en conjunto por ER y Alejandro, escritura que surge del material de archivo donde se refieren hechos de la vida y vocación científica de Alejandro Posadas con quien el autor, ER, tuvo una amistad en el cruce de los siglos XIX al XX. La identidad de los autores ahora sí reales, Eduardo Rudnitzky y Alejandro Tantanian, se desestabiliza al ser incorporados como autores y personajes de la ficción dramática anclada en otro tiempo, dato además aportado desde notas al pie de página, todo un homenaje a los juegos intertextuales y ficcionales del propio Borges. Finalmente ¿quiénes son los que escriben con cierta ironía la dramícula? ¿Quiénes son los autores que aparentan declarar el gesto autobiográfico de la pulsión escrituraria? ¿Fue Alejandro Posadas el autor de los discursos que estos otros dos intentan volver a montar?

La didascalia de presentación citada más arriba, da las claves para leer el texto por fuera de lo que podríamos concebir, no sólo como texto dramático tradicional sino también por la opción que lleva al límite el lenguaje deíctico de toda didascalia. ¿Qué indicación refiere una acotación autoral que propone como

\footnotetext{
${ }^{11}$ Las citas pertenecen a la Colección Nuevo Teatro de Editorial Losada, publicada en 2007.
} 
hipótesis de performatividad escénica el silencio, la mudez, la no referencia? "Carteles mudos sobre el imperio blanco de las imágenes". Pero además, los señalamientos de pasaje de escena a escena cobran el valor poético de la desintegración del propio código, nombrados como "transición", "fundición" y "disolución”, en una insistente pretensión de desconstrucción del género. Fundir y disolver la escena pasada en la escena próxima y la escena en sí misma atenta, no sólo con la natural condición de referencialidad de toda acotación sino también, y esto me parece más importante, con esa peculiaridad de doble enunciación de todo texto dramático. Porque entonces aquí, ya no es dable distinguir entre una voz autoral dirigida a sus alocutarios directos reales (director, actor, auxiliares de escena) y los del texto estrictamente ficcional, es decir el de las interlocuciones de los personajes. Pero además, que las escenas guarden entre sí una relación de transición y además, se disuelvan o fundan una vez exhibidas, habla de un estado de provisionalidad, de poca estabilidad, por no decir de absoluta imposibilidad de perdurabilidad, no sólo de las palabras sino también de las situaciones o historias que tales palabras pretenden referir.

La documentación de la enfermedad de Alejandro Posadas registrada por él mismo en una especie de relato autobiográfico reúne las condiciones como para ser poesía pero ella se desvanece en el pasaje hacia la proyección de imágenes o fotos, denostando irónicamente la discursividad poética y sentenciando, ahora, en favor de lo visual:

Esto lo escribe otra persona

No soy el que documenta mi propia muerte

Cuando yo me pudro

En tierras lejanas

Me morí

En parís.

Hace como cien años

Víctima de una osteoartritis tuberculosa

Soy polvo ahora

Mientras ustedes leen esto

¿está bien el foco así?

Lean entonces

Yo parto ahora

Y los bienvengo

A decir verdad: me obligan a bienvenirlos (36) 
La voz fantasmal que es conciente del carácter ficcional y espectacular de su relato poético a partir de la intervención que interroga sobre la correcta iluminación escénica, se dirige hacia adentro de la ficción, a los autores de la dramícula que están intentando dar una versión escrita del material hallado pero también, hacia afuera de la ficción drámatica, a los espectadores colocados en la inusitada posición de lectores.

Entonces, al juego de remisiones textuales que confunde original y copia y, a la propuesta de intercambiabilidad de, por un lado, géneros discursivos: de la poesía al teatro y al relato; y por otro, de identidades en la figura de los autores reales con los ficticios, se suma una apuesta más de desconstrucción dramática en los señalamientos entre escena y escena a partir de nombrar las indicaciones didascálicas con los términos Fundido, Disolución que son exclusivamente expresiones poéticas que no aportan ningún tipo de performatividad para una puesta en escena futura, sólo la que se deduce del problema de representar la disolución. La voz poética del Dr. Posadas nos coloca en un lugar inestable que transita entre la lectura y la expectación de, primero, un teatro eminentemente visual montado a través de proyecciones fílmicas; segundo, un relato de características fantásticas construido desde las clásicas alteraciones de los paradigmas espacio-temporales lógicos que evidencia; y, por último, de la poesía que excede el discurso marcadamente subjetivo del personaje y desborda contaminando el texto tradicionalmente deíctico, es decir, la acotación.

El apéndice final aporta un procedimiento textual muy borgeano que intenta dar cuenta o explicar el origen de la escritura de la dramícula que sería el inicio de una serie que se anuncia para el futuro, explicación que queda inconclusa y que en nota al pie se aclara que: "De aquí en más la lectura se pierde gracias a la corruptiva acción de la humedad, que supo atacar el corpus de las obras del doctor Alejandro Posadas (23 de mayo de 1966) del Archivo General de la Medicina de la República Argentina." (60).

Se fija como fecha de composición de la obra el 23 de noviembre del 2001, justo un mes antes de los sucesos políticos acaecidos en la Argentina en diciembre del 2001 que finalizaron como todos sabemos que finalizó. No podemos dejar de suponer o hipotetizar que esta disolución entre escena y escena con que transcurre la obra, además de constituirse, como ya dijimos, en un mecanismo eficaz de 
desconstrucción dramática de las acotaciones tradicionales, también pueda relacionarse con la disolución de una Nación a partir del "caso" del gran científico argentino. La parte por el todo y el todo por la parte, concepción tan afín al pensamiento borgeano. La escena final con la que se refiere la muerte de Posadas:

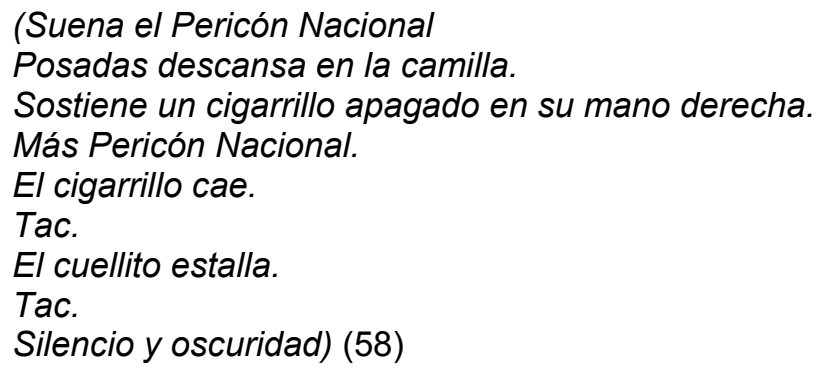

...muestra el funcionamiento de estas ficciones nacionales y políticas que aportan a un imaginario, a una "fábula de identidad" (Montaldo, 1999) que se organiza e impone a partir de la fuerza de la letra, en este caso, la letra del paradigma científico nacional. Aquí se corroe esta letra, se la somete a la prueba de la lectura de su reverso, de la acción del tiempo de los archivos olvidados y abandonados, de la degradación del cuerpo físico como alegoría de la del cuerpo social y nacional, de la ida del gran científico argentino al extranjero. El discurso poético reservado para las interlocuciones íntimas de Posadas es contrapuesto violentamente con lo narrativo y público del discurso oficial, "de la cálida charla confesional al exaltado discurso oficial" que se muestra patéticamente mentiroso ante la exaltación patriótica: "Usted pudo desamar las trampas de la patria, encontrar la salida de la oscuridad, encontrar la luz que cura, y frente a la certeza de descubrimiento, operar con inteligencia de avanzada y filmar, sí filmar: blanco sobre negro, aquellas operaciones extraordinarias, madres de toda la cirugía moderna (...)" (55).

Filmaciones que se encuentran en archivos abandonados o en depósitos de viejos y derruidos edificios. Puesta en escena del proceso de fundición de la patria, de disolución de un caso de orgullo nacional que "va a morir en París" en una especie de ciclo de retorno al período fundacional. 
Si la postura de subalternidad del texto teatral que sostienen no pocas tendencias en el campo de los estudios teatrales, se sustenta en su carácter virtual, dicha virtualidad no es menos que la de cualquier texto de la literatura. El acto de lectura es la instancia en la que se resuelve la virtualidad, tanto para el texto dramático como para cualquier otro texto literario. Todo texto está tramado en esos espacios de lo no dicho, en su dinámica y potencia que implica que cada acto de lectura es uno pero, no el total y monolítico. El texto escrito reclama un acto de lectura. El texto sucede, es un acontecimiento en el acto de lectura más allá de que esa lectura devenga a futuro en representación. Las presencias en escena, surgen de un acto de lectura previo, son la marca o la prueba de la ausencia textual.

Claro que el teatro es una síntesis entre la literatura y otras manifestaciones artísticas y que posee sus peculiaridades pero, para el texto dramático también vale la sentencia que para el resto de los textos literarios, la que profesa que leer es un acto creativo. El privilegio exclusivo del teatro y del cine es concretar materialmente la virtualidad de la lectura. Donar una interpretación peculiar en el espacio en blanco que ofrece la poeticidad, donación que en la lectura de una novela está reservado al ámbito privado y a la virtualidad. El texto dramático sucede en la representación de la misma manera que un poema sucede en el acto de ser leído. La crisis del texto dramático es en realidad la crisis del texto en sí, de los modos de representación artística y de los modos de lectura.

La prescripción final: "Y el resto se hace con gritos", del ensayo de Artaud titulado "El atletismo afectivo" se dirige a los actores. Allí se exponen las analogías entre la musculatura entrenada de los atletas y la emoción y la pasión como los músculos a desarrollar en el entrenamiento actoral. También se dedica a denostar el teatro psicológico occidental de su época con actores "que no saben hacer otra cosa que hablar", y a exaltar en cambio, el eminentemente físico actuado por estos atletas de la emoción sólo reconocibles en el teatro oriental. Frente al habla de los actores adormecidos, el grito exacerbado de un teatro que deberá anclar "para siempre en la poesía y la ciencia". Anteriores al ensayo citado, son las "Cartas sobre el lenguaje" que Artaud escribe en París desde septiembre de 1931 hasta mayo de 1933, cartas en la que el poeta se desvela por independizar el teatro del texto, o mejor por encontrar un justo medio en el que palabra y gesto, lenguaje verbal y lenguaje sígnico logren transgredir las leyes clásicas del teatro: "Así lejos de restringir las 
posibilidades del teatro y del lenguaje, so pretexto de que no presentaré piezas escritas, amplío el lenguaje de la escena y multiplico sus posibilidades" (113).

En principio podríamos afirmar que, efectivamente, hay un límite inaccesible en la teoría de Artaud, un límite paradojalmente autoimpuesto y experimentado de manera angustiante por él mismo. Sin embargo, el teatro contemporáneo, al hacer suyas muchas de sus concepciones, posibilitó la ruptura deseada teóricamente por el vanguardista de la crueldad.

Es cierto que la interpretación universalmente consagrada de la teoría artaudiana es la del teatro sin habla, desprovisto de fines referenciales, sostenido en el gesto, el ademán y la materialidad física, la terrible sentencia de muerte que firma sin titubeos sobre el teatro occidental al considerarlo un soporífero del pensamiento y la emoción. Pero no menos cierto es que un anhelo constante se desprende de sus afirmaciones: el de recuperar la palabra de la poesía: "Yo añado al lenguaje hablado otro lenguaje, y procuro darle al lenguaje del habla, cuyas misteriosas posibilidades se han olvidado, su vieja eficacia mágica, su eficacia hechizadora, integral (...) incluso la parte hablada y escrita lo será en un sentido nuevo." (cita de Antonin Artaud, en Derrida, 1989:329).

Si además de las cartas y de los manifiestos de la crueldad, leemos El pesanervios, El ombligo de los limbos, entendemos que la pretensión de Artaud no es menos que la del rescate de una lengua viva y libre para el teatro tan atrevida como la de la poesía, la asunción de un lenguaje que corra el riesgo de comunicar y emocionar desde una palabra vaciada de la doxa de la verdad. Deleuze señala en la literatura de Lewis Carol algo que resuena como eco artaudiano y que se proyecta hacia la escritura dramática actual: no se trata de simples juegos de palabras sino de acontecimientos de lenguaje capaces de crear realidades. "Hay que luchar contra el lenguaje, inventar el tartamudeo, para trazar una vocal escrita que hará correr el lenguaje entre esos dualismos y que definirá un uso minoritario del lenguaje, una variación".

El hacer con gritos lo que resta no significa la ausencia de la palabra en el teatro sino la presencia de ella con la potencia inusitada de la literatura en una suerte de repetición de un ciclo que no sintetiza ni condensa ni homologa sino, que dispersa, disemina, distorsiona. 


\section{Bibliografía}

Apolo, I. (2002): "Tesis para el análisis del texto dramático", en Gestos: teoría y práctica del teatro hispánico, $\mathrm{N}^{\circ} 33,9-34$.

(2003): "(Muere) -espacio y tiempo en el texto dramático-", en El teatro y su doble, Artaud, A.; (1979) [1964]. Sudamericana, Buenos Aires.

Bertuccio, M.; Stella, T.; Zangaro, P. (2003): Cómo se escribe una obra teatral. Libros del Rojas, Buenos Aires.

Caraja-ji/La disolución (1997): Libros del Rojas, Buenos Aires.

Celis Álvarez, M. (2005): "La escena expandida" en Revista Artes, № 10, Vol. 5, julio-diciembre 2005, Facultad de Artes, Universidad de Antioquía.

Deleuze, G - Parnet, C. (1980): Diálogos. Editorial Pretextos, Paris, 1977.

Deleuze, G. (2003): “Un Manifiesto Menos", en Superposiciones, Carmelo, Bene/Deleuze, Gilles. Artes Del Sur, Buenos Aires, 1979.

Derrida, J. (1989): "La palabra soplada" y "El teatro de la crueldad y la clausura de la representación", en La escritura y la diferencia. Anthropos, Barcelona.

Diéguez, I. (2007): Escenarios liminales. Teatralidades, performances y política. Atuel, Buenos Aires

Dubatti, J. (1999): El teatro laberinto. Atuel, Buenos Aires. (2002): El teatro jeroglífico. Atuel, Buenos Aires. (2008): Cartografía teatral. Introducción al Teatro Comparado. Atuel, Buenos Aires. Feral, J. (2004): Teatro, teoría y práctica: más allá de las fronteras. Galerna, Buenos Aires.

Gerbaudo, A. (2007): Derrida y la construcción de un nuevo canon crítico para las obras literarias. Universitas Libros, FFy H., Córdoba.

Kartún, M. (2001): Escritos. Libros del Rojas, Buenos Aires.

Monti, R. (2002): Narradores y Dramaturgos. Universidad Nacional del Litoral e Instituto Nacional del Teatro, Santa Fe.

Pellettieri, O. (1994): Cien años de teatro argentino. Galerna, Buenos Aires.

Piglia, R. (2002): en Narradores y Dramaturgos. Universidad Nacional del Litoral e Instituto Nacional del Teatro, Santa Fe.

Tantanián, A. (2007): Cine Quirúrgico Colección Nuevo Teatro. Editorial Losada, Buenos Aires. 
Ubersfeld, A. (2002): Diccionario de términos claves del análisis teatral. Galerna, Buenos Aires.

Veltrusky, J. (1990): El drama como literatura. Galerna, Buenos Aires. 